\title{
Hepatoprotective activity of Ehretia microphylla on paracetamol induced liver toxic rats
}

\author{
Kumarapalayam Ramakrishnan YUVARAJA $1 *$ (D), Arockiasamy SANTHIAGU 2 (D), \\ Shabbeer JASEMINE ${ }^{3}$ (D) , Kasiramar GOPALASATHEESKUMAR 4 (D)
}

1 Department of Pharmaceutical Chemistry, Faculty of Pharmacy, KMCH College of Pharmacy, Coimbatore, Tamil Nadu-641048, India.

2 Department of Biotechnology, School of Biotechnology, National Institute of Technology, Calicut, Kerala, India.

3 Director, One Beat College of Medical Sciences, Bhira, Uttar Pradesh, India.

4 Department of Pharmacy, Faculty of Engineering and Technology, Annamalai University, Annamalai Nagar, Tamil Nadu - 608002, India.

* Corresponding Author. E-mail: yuvarajakr1@gmail.com (KR.Y.); Tel. +91-889-1916931.

Received: 18 July 2020 / Revised: 04 November 2020/ Accepted: 20 November 2020

\begin{abstract}
World wide liver toxicity is the most prevelent healthcare problem. We need to address this with herbal based medicine because herbal products have high efficacy and less side effects. Many of the Ehretia genus (Boraginaceae) have the hepatoprotective property. But Ehretia microphylla (EM) was not reported yet for its hepaptoprotective potential. Therefore the current research was aimed to evaluate the hepatoprotective action of EM. The hepatoprotective activity of EM was assessed against the paracetamol induced liver toxic rats. The chloroform and ethyl acetate extracts of EM were selected for the investigation. The dose was selected by using OECD423 guidelines. The paracetamol intoxicated rats were elevated the liver functional parameters like serum SGOT, SGPT and ALP levels and also triglyceride and total cholesterol. These elevated parameters were significantly lowered in chloroform and ethyl acetate extracts of EM pretreated rats when compared with silymarin. However the antioxidant markers including CAT, SOD, GSH and GPx were significantly increased in EM extract treated rats when compared with paracetamol induced toxic rats. It revealed the plant extracts of EM has significant hepatoprotective activity. Further, this research will useful for the isolation of active principles from EM and determining its molecular mechanisms.
\end{abstract}

KEYWORDS: Liver; silymarin; antioxidant; Boraginaceae; Ehretia.

\section{INTRODUCTION}

Liver is the vital organ in the human body which consisting of many of the metabolic enzymes which metabolize the carbohydrate, proteins and fats etc. Liver is also involved in the immune function to maintaining body integrity [1]. The world was affected by chronic liver disease irrespective of sex, age, region or race. Reports of $\mathrm{WHO}$ revealed the $46 \%$ of global diseases and $59 \%$ of the mortality is reason for chronic diseases (cardiovascular diseases; mainly heart disease and stroke; cancer; respiratory diseases; liver diseases and diabetes) and almost 35 million people in the world die because of chronic diseases [2]. The UK National statistics reports that the liver diseases are the fifth common death causing ailment $[3,4]$. Medicinal plants and herbal extracts are plays an important role in hepatoprotective activity [5].

Ehretia microphylla (EM) (Family: Boraginaceae) is one of the most important medicinal plants in the Philippines and other Asian Countries, and it has variety of medicinal values. The decoction of the leaves used as cough suppressant, and it is prescribed for the treatment of diarrhea with bloody discharge and dysentery [6, 7]. The antioxidant [8], antimicrobial [9], anti-hypercholesterolemic [10], anti-allergic [11] activities have been reported in scientific platform.

Many of the herbalsfrom Ehretia genus have been reported for its hepatoprotective activity [12]. Moreover the anticancer activity of quercetin isolated from EM against HepG2 human liver cancer cell line has been reported [13]. And also, many of the anticancer herbals against hepatocellular carcinoma (liver cancer) have reported for their hepatoprotective activity $[14,15,16]$. However, there are no scientific reports for hepatoprotective activity of EM. Preliminary studies conducted by our lab have reported the antioxidant

How to cite this article: Yuvaraja KR, Santhiagu A, Jasemine S, Gopalasatheeskumar K. Hepatoprotective activity of Ehretia microphylla on paracetamol induced liver toxic rats. J Res Pharm. 2021; 25(1): 89-98. 
and free radical scavenging activity of EM [17]. Furthermore free radical scavenging and antioxidant mechanisms are associated with hepatoprotective activity [18]. Therefore the current research work was designed to evaluate the hepatoprotective activity of EM.

\section{RESULTS AND DISCUSSION}

The results of acute oral toxicity study are shown in Table 1.

Table 1. Acute toxicity study of ethyl acetate and chloroform extracts of Ehretia microphylla.

\begin{tabular}{clllllll}
\hline \multirow{2}{*}{ S. no } & \multirow{2}{*}{ Response } & \multicolumn{2}{c}{ Head } & \multicolumn{2}{c}{ Body } & \multicolumn{2}{c}{ Tail } \\
& & Before & After & Before & After & Before & After \\
\hline $\mathbf{1}$ & Alertness & Normal & Normal & Normal & Normal & Normal & Normal \\
$\mathbf{2}$ & Grooming & Absent & Absent & Absent & Absent & Absent & Absent \\
$\mathbf{3}$ & Torch response & Normal & Normal & Normal & Normal & Normal & Normal \\
$\mathbf{4}$ & Pain response & Normal & Normal & Normal & Normal & Normal & Normal \\
$\mathbf{5}$ & Tremor & Absent & Absent & Absent & Absent & Absent & Absent \\
$\mathbf{6}$ & Convulsion & Absent & Absent & Absent & Absent & Absent & Absent \\
$\mathbf{7}$ & Righting reflux & Normal & Normal & Normal & Normal & Normal & Normal \\
$\mathbf{8}$ & Gripping strength & Normal & Normal & Normal & Normal & Normal & Normal \\
$\mathbf{9}$ & Pinna reflux & Present & Present & Present & Present & Present & Present \\
$\mathbf{1 0}$ & Corneal reflux & Present & Present & Present & Present & Present & Present \\
$\mathbf{1 1}$ & Writhing & Absent & Absent & Absent & Absent & Absent & Absent \\
$\mathbf{1 2}$ & Pupils & Normal & Normal & Normal & Normal & Normal & Normal \\
$\mathbf{1 3}$ & Urination & Normal & Normal & Normal & Normal & Normal & Normal \\
$\mathbf{1 4}$ & Salivation & Normal & Normal & Normal & Normal & Normal & Normal \\
$\mathbf{1 5}$ & Skin colour & Normal & Normal & Normal & Normal & Normal & Normal \\
$\mathbf{1 6}$ & Lacrimation & Normal & Normal & Normal & Normal & Normal & Normal \\
\hline
\end{tabular}

Acute toxicity studies of ethyl acetate and chloroform extracts of EM revealed the safety dose of dose until $2000 \mathrm{mg} / \mathrm{kg}$. Hence the dose fixed for study as $\left(1 / 20^{\text {th }}\right) 100 \mathrm{mg} / \mathrm{kg}$ as low dose and $\left(1 / 10^{\text {th }}\right) 200 \mathrm{mg} / \mathrm{kg}$ as high dose for EM.

Liver necrosis in paracetamol (PCM) induced rats increases the activities of Serum Glutamic Pyruvate Transaminase (SGPT), Serum Glutamic Pyruvate Oxaloacetate (SGOT) and Serum Alkaline Phosphatase (ALP) in plasma by leakage of these enzymes from liver cytosol into the blood stream [19].These biochemical parameters of various treatment groups were shown in Table 2.

The Serum SGOT, SGPT and ALP levels were increased significantly $(\mathrm{p}<0.001)$ in PCM induced rats compared to normal controlled rats. The standard and extracts treated groups significantly $(\mathrm{p}<0.05)$ reduced these level compared to PCM induced group. The PCM intoxicated rats showed significant increase of triglyceride (TG) and total cholesterol (TC). The possible mechanism for hyperlipidemic condition might be worsening the liver cells which are essential for lipid metabolism. Another probable mechanism for increased serum lipid level may be recognized by increased synthesis of hepatic cells and decreased liver degradation [20]. Values of treatment groups were decreased towards normal when compared with PCM control animals. Serum bilirubin level is the key parameter to find the normal liver function [21]. Values of treatment groups were decreased towards normal when compared with PCM control animals.

The reactive oxidant species and/or lipid peroxidase are normally deactivated by the antioxidant enzymes like Catalase (CAT), Superoxide dismutase (SOD), Reduced glutathione (GSH) and Glutathione peroxidase (GPx). These antioxidant enzyme activities are drastically decreased in PCM intoxicated rats, the plant extracts protect significantly decreased CAT, SOD, GSH and GPx levels when compared to the rats treated with control groups [22]. PCM intoxicated rats showed acute liver necrosis thereby increased level of lipid peroxidation (LPO). This is counteracted by plant extracts and standard. The CAT, SOD, GSH and GPx values of extracts and standard treated groups are shown in Table 3. 
Table 2. Effect of plant extracts and standard against PCMinduced liver toxic rats (serum biochemical markers).

\begin{tabular}{|c|c|c|c|c|c|c|c|c|}
\hline $\begin{array}{l}\text { Treatment } \\
\text { Group }\end{array}$ & $\begin{array}{l}\text { SGPT } \\
\text { (U/L) }\end{array}$ & $\begin{array}{c}\text { SGOT } \\
(\mathrm{U} / \mathrm{L})\end{array}$ & $\operatorname{ALP}(\mathrm{U} / \mathrm{L})$ & $\begin{array}{c}\text { HDL } \\
\text { (mg/dl) }\end{array}$ & $\begin{array}{c}\text { TG } \\
\text { (mg/dl) }\end{array}$ & $\begin{array}{c}\text { TC } \\
(\mathrm{mg} / \mathrm{dl})\end{array}$ & $\begin{array}{c}\text { TB } \\
(\mathrm{mg} / \mathrm{dl})\end{array}$ & $\begin{array}{c}\text { DB } \\
(\mathrm{mmol} / \mathrm{l})\end{array}$ \\
\hline \multirow{2}{*}{ Group I } & 66.16 & 99 & 170.51 & 53 & 103 & 80 & 0.8 & 0.2 \\
\hline & \pm 7.98 & \pm 2.09 & \pm 11.6 & \pm 3.90 & \pm 2.08 & \pm 2.03 & \pm 0.01 & \pm 0.02 \\
\hline \multirow{2}{*}{ Group II } & 398 & 153 & 318.61 & 28 & 379 & 347 & 2.8 & 0.8 \\
\hline & $\begin{array}{c} \pm 3.07 \pi \pi \\
\#\end{array}$ & $\pm 5.08^{\# \# \# ~}$ & $\pm 3.95^{\#}$ & $\pm 1.28^{\# \#}$ & $\pm 3.81 \# \#$ & $\pm 1.22^{\# \#}$ & $\pm 0.01^{\# \#}$ & \pm 0.01 \#\#\# \\
\hline \multirow{2}{*}{ Group III } & 261 & 125 & 250 & 47 & 203 & 113 & 1.3 & 0.196 \\
\hline & $\pm 3.47^{* * *}$ & $\pm 3.96^{* * *}$ & $\pm 1.68^{* * *}$ & $\pm 2.97^{* * *}$ & $\pm 3.95^{* * *}$ & $\pm 1.98^{* * *}$ & $\pm 0.02^{* \star *}$ & $\pm 0.03^{* * *}$ \\
\hline \multirow{2}{*}{ Group IV } & 227 & 102 & 195 & 49 & 158 & 107 & 1.2 & 0.261 \\
\hline & $\pm 2.68^{* *}$ & $\pm 1.37^{\star \star \star}$ & $\pm 4.08^{* *}$ & $\pm 7.04^{* *}$ & $\pm 2.66^{* *}$ & $\pm 3.08^{* *}$ & $\pm 0.01^{* *}$ & $\pm 0.03^{* \star *}$ \\
\hline \multirow{2}{*}{ Group V } & 250 & 115 & 263 & 37 & 243.7 & 128 & 1.5 & 0.255 \\
\hline & $\pm 2.95^{\star *}$ & $\pm 3.67^{* \star \star}$ & $\pm 2.95^{\star *}$ & $\pm 5.08^{*}$ & $\pm 2.81^{* *}$ & $\pm 2.96^{* *}$ & $\pm 0.03^{* *}$ & $\pm 0.01^{\star \star \star}$ \\
\hline \multirow{2}{*}{ Group VI } & 216 & 105 & 225.8 & 43 & 191.7 & 126.6 & 1.22 & 0.189 \\
\hline & $\pm 5.65^{* *}$ & $\pm 3.56^{* *}$ & $\pm 3.07^{*}$ & $\pm 4.93^{* *}$ & $\pm 5.03^{*}$ & $\pm 3.28^{*}$ & $\pm 0.03^{* *}$ & $\pm 0.02^{* * *}$ \\
\hline \multirow{2}{*}{ Group VII } & 230 & 118 & 255 & 40 & 187 & 115.4 & 1.47 & 0.38 \\
\hline & $\pm 3.62^{*}$ & $\pm 2.78^{* *}$ & $\pm 7.08^{* *}$ & $\pm 3.28^{* *}$ & $\pm 3.33^{* *}$ & $\pm 3.77^{* *}$ & $\pm 0.02^{* *}$ & $\pm 0.01^{\text {** }}$ \\
\hline Group & 215 & 103 & 210 & 45 & 160.9 & 109.98 & 1.2 & 0.3 \\
\hline VIII & $\pm 5.91^{* *}$ & $\pm 3.35^{\text {** }}$ & $\pm 5.83^{\text {** }}$ & $\pm 2.68^{* *}$ & $\pm 2.55^{\star *}$ & $\pm 2.52^{*}$ & $\pm 0.03^{* *}$ & $\pm 0.01^{\text {** }}$ \\
\hline
\end{tabular}

Data is expressed as mean \pm SEM, $n=6$, One way ANOVA followed by Dunnett's test Compared with normal control; \# $\mathrm{p}<0.05$, \#\# $\mathrm{p}<0.01$, \#\#\# $\mathrm{p}<0.001$, Compared with disease control; ${ }^{*} \mathrm{p}<0.05,{ }^{* *} \mathrm{p}<0.01,{ }^{* * *} \mathrm{p}<0.001$.

Table 3. Effect of plant extracts and standard against PCM induced liver toxic rats (Antioxidant markers).

\begin{tabular}{|c|c|c|c|c|c|}
\hline $\begin{array}{l}\text { Treatment } \\
\text { Group }\end{array}$ & $\begin{array}{c}\text { CAT } \\
(\mathrm{H} 2 \mathrm{O} 2 \\
\text { consumed } / \mathrm{min} / \mathrm{mg} \\
\text { of protein) }\end{array}$ & $\begin{array}{c}\text { SOD } \\
\text { (unit/min/mg } \\
\text { protein) }\end{array}$ & $\begin{array}{c}\text { GSH } \\
\text { (unit/min/mg } \\
\text { of protein) }\end{array}$ & $\begin{array}{c}\text { GPx } \\
\text { (GSH } \\
\text { consumed/ } \\
\text { min/mg } \\
\text { protein) }\end{array}$ & $\begin{array}{c}\text { LPO } \\
\text { (MDA per mg } \\
\text { of protein) }\end{array}$ \\
\hline Group I & $276.12 \pm 7.16$ & $90.41 \pm 3.65$ & $41.67 \pm 1.29$ & $115.07 \pm 1.16$ & $4.28 \pm 0.81$ \\
\hline Group II & $91.71 \pm 15.15^{\# \# \# ~}$ & $37.32 \pm 2.11^{\# \# \#}$ & $19.86 \pm 2.13$ \#\#\# & 41.67士2.19\#\#\# & $85.19 \pm 0.91^{\# \# \#}$ \\
\hline Group III & $219.61 \pm 6.76^{* * *}$ & $69.13 \pm 3.15^{\text {*** }}$ & $36.18 \pm 1.76^{* *}$ & $91.73 \pm 3.12^{* * *}$ & $10.16 \pm 1.21^{* * *}$ \\
\hline Group IV & $265.12 \pm 5.67^{\star \star * *}$ & $85.91 \pm 2.91^{\text {*** }}$ & $40.36 \pm 3.61^{* * *}$ & $110.09 \pm 2.16^{* * *}$ & $5.93 \pm 0.16^{* * *}$ \\
\hline Group V & $146.12 \pm 1.25^{\star \star \star}$ & $42.02 \pm 1.94^{\star * *}$ & $24.25 \pm 0.26^{* *}$ & $59.45 \pm 0.41^{* * *}$ & $20.12 \pm 0.36^{\star * *}$ \\
\hline Group VI & $242.18 \pm 0.12^{\star \star *}$ & $62.10 \pm 1.95^{\star * *}$ & $29.16 \pm 0.25^{\star * *}$ & $95.21 \pm 0.28^{* * *}$ & $10.02 \pm 0.34^{* *}$ \\
\hline $\begin{array}{l}\text { Group } \\
\text { VII }\end{array}$ & $168.11 \pm 3.12^{* *}$ & $51.92 \pm 4.51^{*}$ & $34.73 \pm 2.91^{* * *}$ & $79.67 \pm 3.16^{* * *}$ & $14.91 \pm 0.12^{\star \star \star}$ \\
\hline $\begin{array}{l}\text { Group } \\
\text { VIII }\end{array}$ & $262.19 \pm 2.15^{* *}$ & $81.12 \pm 2.96^{* *}$ & $39.18 \pm 1.28^{* * *}$ & $107.31 \pm 1.29^{* * *}$ & $6.01 \pm 0.24^{* \star \star}$ \\
\hline
\end{tabular}

Data is expressed as mean \pm SEM, $n=6$, One way ANOVA followed by Dunnett's test Compared with normal control; \# $\mathrm{p}<0.05, \# \# \mathrm{p}<0.01$, \#\#\# p<0.001, Compared with disease control; $\mathrm{p}<0.05,{ }^{* *} \mathrm{p}<0.01,{ }^{* * *} \mathrm{p}<0.001$.

Values of treatment groups were increased towards normal when compared with PCM Control animals. Across all the extract treatment groups "PCM + EAEM 200mg/kg Group" showed maximum activity, when compared with "PCM + SLY $100 \mathrm{mg} / \mathrm{kg}$, Group".

The results of the histopathological study are shown in Figure 1. Group I Normal control, Liver shows normal lobular architecture, hepatocytes show no significant pathology, Group II PCM induced control hepatocytes show cytoplasmic vacuolation, periportal inflammation and central vein shows congestion destruction, Group III SLY $50 \mathrm{mg} / \mathrm{kg}$ treated PCM control- portal traid shows mild periportal inflammation, Group IV SLY $100 \mathrm{mg} / \mathrm{kg}$ treated PCM control liver shows normal portal tracts, the hepatocytes in the hepatic parenchyma are normal, Group V CEM 100mg/kg treated PCM control shows mild hydropic changes in the hepatocytes of centrilobular region, the sinusoids are mildly dilated, Group VI CEM 200 $\mathrm{mg} / \mathrm{kg}$ treated PCM control liver shows extensive necrosis in the centrilobular region, Group VII EAEM 100 $\mathrm{mg} / \mathrm{kg}$ treated PCM control- liver section shows extensive necrosis in the centrilobular region and Group VIII EAEM $200 \mathrm{mg} / \mathrm{kg}$ treated PCM control shows sinusoids are dilated, there is no significant necrosis seen. 
The liver damage associated with PCM overdose is due to the formation of the hepatotoxic metabolite. The liver toxicity in rats, damages the normal morphology of liver cells and formation of cytoplasmic vacuolation, periportal inflammation, central vein destruction, hydropic changes and dilated sinusoids. These morphological damages were regained by CEM and EAEM. It might be associated with the phytoconstituents (Flavonoids, phenolic compounds, glycosides, and phytosterols) present in the extracts.
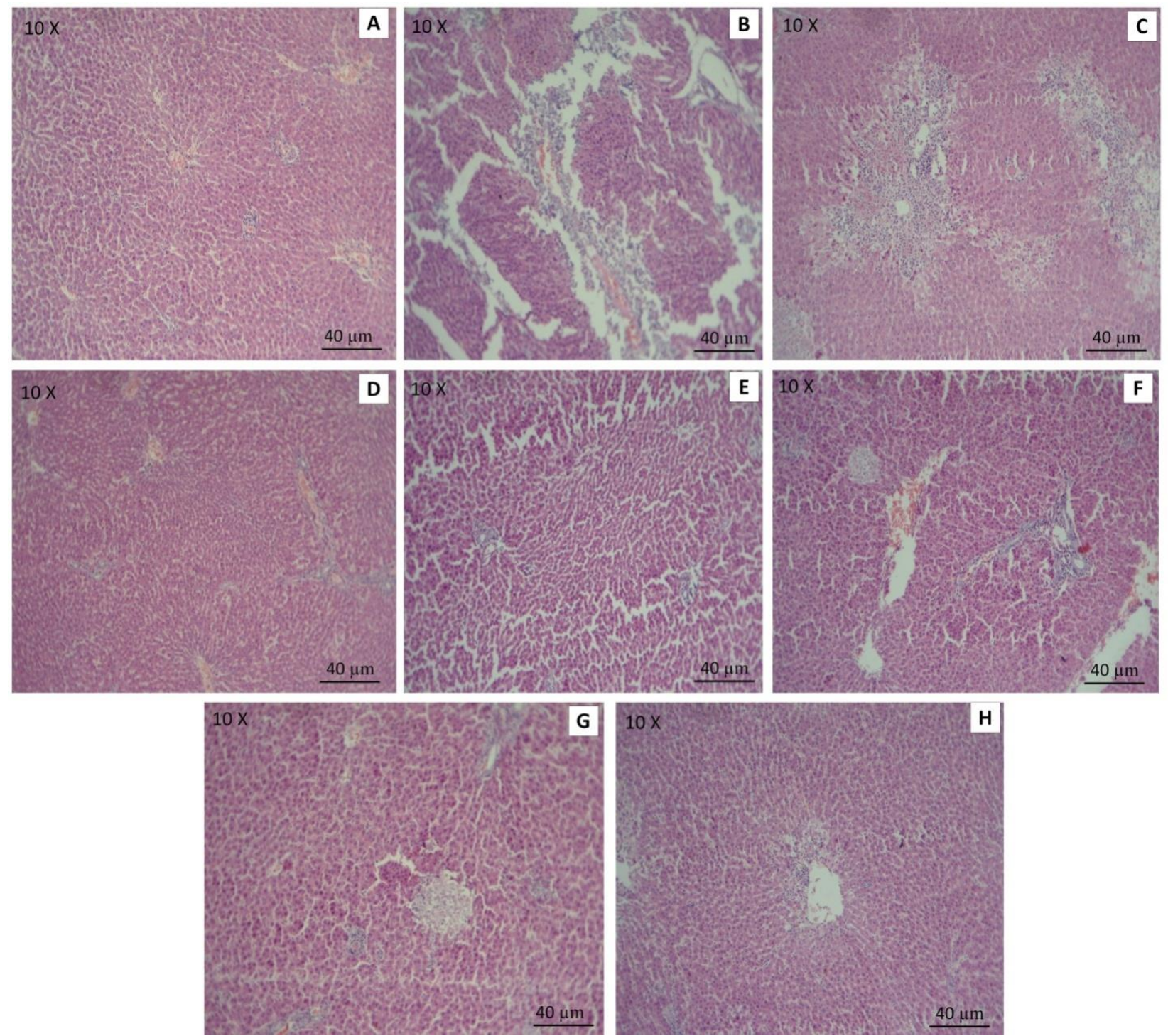

Figure 1. Histopathology of Liver. A: Group I, B: Group II, C: Group III, D: Group IV, E: Group V, F: Group VI, G: Group VII, H: Group VIII. Magnifications at 10X.

EM is one of the important medicinal plants widely used in tribes of Philippines and other Asian Countries for the management of many diseases. EM has reported many biological activity in scientific platform and has not been reported its hepatoprotective activity. The results of the present research revealed that the EMEM and CEM have significant hepatoprotective activity. This research work is the first report for hepatoprotective activity of EM. PCM induced liver toxicity is the widely used model for screening of hepatoprotective drugs. Due to the overdose of PCM lead to cause liver injury in rat through hepatic necrosis caused by the reactive $\mathrm{N}$-acetylimidoquinone metabolite of PCM[23]. The EM treated animals shown significant action on lower the toxicity.

Our previous research reported for antioxidant activity of EM. The overproduction of Reactive oxygen species due to liver necrosis can worsen the quantum of oxidative stress leading to combining mechanism of injury associated with liver damage. Antioxidant enzymes such as SOD, CAT, and GPx play a significant role in the prevention of tissue damage. In current research PCM toxic rats declined the antioxidant enzymes 
in liver homogenate and EM shows significant improvement of antioxidant enzymes. This result suggest that the antioxidant mechanism of EM might be the reason for its hepatoprotective activity. Furthermore we have already quantified the total phenolic and flavonoid contents. These flavonoids and phenolic compounds are having potent antioxidant capacity in literature[24]. So that the hepatoprotective activity responsible compounds from EM is maybe the phenolics or flavonoids derivative.

\section{CONCLUSION}

In conclusion, the chloroform and ethyl acetate extract of EM produced significant hepatoprotective activity against PCM toxic rats. The hepatoprotective activity of EM might be the presence of phenolic and flavonoid compounds. Further study needed to isolation of active principles and development of formulation for commercialization.

\section{MATERIALS AND METHODS}

\subsection{Materials}

The aerial parts of EM was collected locally Sattankulam at Thuthukudi District in Tamil Nadu state in India. PCMand Silymarin (SLY) were purchased from Sigma Aldrich, USA. Petroleum ether, chloroform, ethyl acetate and methanol were obtained from SD Fine Chemicals Pvt. Ltd, Mumbai, India. Ketamine hydrochloride was obtained from KMCH Pharmacy, Coimbatore. The experimental animals were procured from Sri Venkateshwara Enterprises, Bangalore, India. Sodium carboxyl methyl cellulose, formalin, glacial acetic acid, n-butanol, sodium azide, sodium dodecyl sulfate, hydrochloric acid and Tris-HClwere procured from Merck (India) Ltd., Mumbai. SGOT, SGPT, ALP, total bilirubin (TB), direct bilirubin (DB),TC, TG, highdensity lipoproteins (HDL)- cholesterol level and low-density lipoproteins (LDL) cholesterol level kits were purchached from Span diagnostics, Surat, India. Ellman's reagent, Tri chloro acetic acid (TCA), glutathione reduced solution, sodium pyrophosphate buffer, phenazine methosulphate, nitroblue tetrazolium, Nicotinamide adenine dinucleotide (NADH), thiobarbituric acid (TBA), 1,1,3,3,-tetra-ethoxypropane and hydrogen peroxide were purchased from Himedia Laboratorıes, Mumbai, India.

\subsection{Preparation of plant material}

The aerial parts of EM was authenticated by Dr. V. Chelladurai, Survey of Medicinal and Aromatic plants Unit Siddha, CCRAS (Central Council for Research in Ayurvedic Sciences), Palayamkottai, Tamil $\mathrm{Nadu}$, India, and voucher specimen (SBTH 11.12) was deposited in the Department of School of Biotechnology, NITC, Calicut, Kerala for future reference. After removing of the earthy matters, the aerial parts were washed and shade dried and powdered using a micro pulverizer and the powder passed through sieve no. 40\# [25].

\subsection{Extraction of plant material}

Powdered plant material was subjected to continuous hot extraction method by using soxhlet apparatus. Increasing orders of polarity solvents (petroleum ether, chloroform, ethyl acetate and methanol) were used[26]. The plant material $(1 \mathrm{~kg})$ was of finely powdered and extracted with $5 \mathrm{~L}$ of petroleum ether in a soxhlet apparatus for $72 \mathrm{~h}$, after the successive extraction, the obtained marc was further extracted with solvents of increasing order of polarity (Chloroform, Ethyl acetate and Methanol) [27]. After extraction the extracts were separately concentrated under vacuum using rotary vacuum evaporator at $40^{\circ} \mathrm{C}$ until get viscous solid mass. The obtained crude extracts were weighed and stored at $4^{\circ} \mathrm{C}$ for the further analysis.

\subsection{Experimental animals}

Male albino Wistar rats (150-200 g) were used. The animals were procured from Sri Venkateshwara Enterprises, Bangalore, India. All the animals were kept under standard laboratory conditions (temperature $25 \pm 2^{\circ} \mathrm{C}$ and $12 \mathrm{~h}$ light $/ 12 \mathrm{~h}$ dark cycle) and acclimatized for 1 week before commencement of the experiment. They were allowed to have free access to standard pellet diet (National Institute of Nutrition, Hyderabad, India) and water ad libitum. The protocol used in the present study was approved by Animal Ethics Committee of $\mathrm{KMCH}$ College of pharmacy in accordance with the guidelines for the care and use of laboratory animals set by CPCSEA (KMCRET/PhD/01/2013-14). 


\subsection{Acute oral toxicity study}

The OECD-423 guidelines were used for acute oral toxicity study to fixing the dose for in vivo study. The rats were fasted overnight with free excess to water and were grouped into four with each group consisting of 3 animals, to which the extract was administered orally at the dose level of $5 \mathrm{mg} / \mathrm{kg}$, $50 \mathrm{mg} / \mathrm{kg}$, $300 \mathrm{mg} / \mathrm{kg}$ and $2000 \mathrm{mg} / \mathrm{kg}$ body weight. They were observed for mortality; toxic symptoms such as behavioral changes, locomotor activity, convulsions; direct observation parameters such as tremor, convulsion, salivation, diarrhoea, sleep, coma, changes in skin and fur, eyes and mucous membrane, respiratory, circulatory, autonomic and CNS, somatomotor activity, periodically for 30 min during first $24 \mathrm{~h}$ and specific attention given during first $4 \mathrm{~h}$ daily for a total period of 14 days.

\subsection{In vivo hepatoprotective activity}

Based on the preliminary study conducted by our lab, CEM (Chloroform extract of EM) and EAEM (Ethyl acetate extract of EM) were selected for in vivo evaluation of hepatoprotective activity [16]. Male Wistar albino rats were divided into eight groups of 6 animals each and received orally the following treatment for seven days. The doses were freshly suspended in $1 \%$ sodium carboxyl methyl cellulose for each day of treatment.

- $\quad$ Group I: Normal control rats received 1\% sodium carboxyl methyl cellulose

- $\quad$ Group II: PCM control rats received 1\% sodium carboxyl methyl cellulose

- $\quad$ Group III: Standard low dose rats received SLY 50mg/kg, p.o.

- $\quad$ Group IV: Standard high dose rats received SLY 100 mg/kg, p.o.

- Group V: CEM low dose rats received CEM $100 \mathrm{mg} / \mathrm{kg}$, p.o.

- Group VI: CEM high dose rats received CEM 200mg/kg, p.o.

- $\quad$ Group VII: EAEM low dose rats received EAEM 100mg/kg, p.o.

- $\quad$ Group VIII: EAEM high dose rats received EAEM 200mg/kg, p.o.

Above all the groups except Group I was administrated with $1000 \mathrm{mg} / \mathrm{kg}$ of PCM orally on 7 th day of treatment [28]. After 24h of PCM administration, all the animals were anesthetized using ketamine hydrochloride ( $87 \mathrm{mg} / \mathrm{kg}$, i.p) and blood samples were collected from retro-orbital plexus [29, 30]. The blood samples were allowed to clot for $1 \mathrm{~h}$ at room temperature and the serum was separated by centrifugation at $2500 \mathrm{rpm}$ at $4^{\circ} \mathrm{C}$ for $15 \mathrm{~min}$. Then the rats were sacrificed by cervical dislocation and the liver was excised, washed and perfused with ice-cold normal saline[31]. The perfused liver samples were then homogenized in ice bath using homogenizer in chilled $10 \mathrm{mM}$ Tris- $\mathrm{HCl}(\mathrm{pH}$ 7.4) to yield $10 \%(\mathrm{w} / \mathrm{v})$ liver homogenate for the estimation of biochemical parameters. A small portion of the liver tissue was fixed in formalin for histopathological examination [32, 33, 34, 35].

\subsection{Estimation of serum biochemical parameters}

The SGOT, SGPT, ALP, TB, DB, TG, TC, HDL and LDL levels were estimated by using auto analyzer with the help of standard enzymatic kits and the procedures were performed as per enzymatic kits protocols $[36,37,38]$.

\subsection{Estimation of in vivo antioxidant markers}

After treatment with plant extracts and standard, the rats were sacrificed, liver were isolated and washed with normal saline and stored for $12 \mathrm{~h}$ for in vivo antioxidant studies [39]. The separated liver was homogenized with motor driven Teflon coated homogenizer with $0.1 \mathrm{M}$ Tris- $\mathrm{HCl}$ buffer (pH 7.4) to get $10 \%$ homogenate.

\subsubsection{Catalase (CAT)}

The CAT activity was assayed by the method of Sinha[40]. About $0.1 \mathrm{ml}$ of liver homogenate was added with $1 \mathrm{ml}$ of phosphate buffer and hydrogen peroxide. Then the reaction was stopped by the addition of $0.2 \mathrm{ml}$ dichromate acetic acid reagent. The reaction mixturewas heated in a boiling water bath for $10 \mathrm{~min}$. The green color developed was read at $570 \mathrm{~nm}$ in a Double beam UV-VIS spectrophotometer. Similar procedure was carried out for standard hydrogen peroxide (4 to $20 \mu \mathrm{l})$.CAT content present in the liver 
homogenates was calculated by interpolation. CAT activity was expressed as $\mathrm{H} 2 \mathrm{O} 2$ consumed $/ \mathrm{min} / \mathrm{mg}$ of protein.

\subsubsection{Reduced glutathione (GSH)}

GSH was estimated by Ellman's procedure[41]. To $250 \mu \mathrm{l}$ of liver homogenate was mixed with $1 \mathrm{ml}$ of $5 \%$ TCA in a $2 \mathrm{ml}$ eppendorf tube, and the mixture was centrifuged at $3000 \mathrm{~g}$ for $10 \mathrm{~min}$ at room temperature. To $250 \mu \mathrm{l}$ of the above supernatant was added with $1.5 \mathrm{ml}$ of $0.2 \mathrm{M}$ phosphate buffer and mixed well. Then the reaction was stopped with $250 \mu \mathrm{l}$ of $0.6 \mathrm{mM}$ of Ellman's reagent and the absorbance was measured at $412 \mathrm{~nm}$ within $10 \mathrm{~min}$. A standard graph was plotted using glutathione reduced solution (0.1-1 $\mathrm{mg} / \mathrm{ml}$ ) and the amount of GSH present in the liver homogenates was calculated by interpolation. Amount of glutathione expressed as unit $/ \mathrm{min} / \mathrm{mg}$ of protein.

\subsubsection{Superoxide dismutase (SOD)}

About $250 \mu$ l of liver homogenate was mixed with $1.2 \mathrm{ml}$ of sodium pyrophosphate buffer, $0.1 \mathrm{ml}$ of phenazinemethosulphate, and $0.3 \mathrm{~mL}$ of nitroblue tetrazolium and appropriately diluted enzyme preparation in a total volume of $3 \mathrm{ml}$. Then the mixture was added with $0.2 \mathrm{ml} \mathrm{NADH}$. And the mixture was heated at $30^{\circ} \mathrm{C}$ for $2 \mathrm{~min}$, the $1 \mathrm{ml}$ glacial acetic acid was added to stop the reaction. The mixture was separaded with adding of n-butanol. Then the n-butanol layer color was measured in a colorimeter at 520 $\mathrm{nm}$. The specific activity of the enzyme was expressed as unit $/ \mathrm{min} / \mathrm{mg}$ protein[42].

\subsubsection{Estimation of Glutathione peroxidase (GPx)}

GPx was measured by the method described by Rotruck et al. About $0.2 \mathrm{ml}$ of liver homogenate was mixed with $0.2 \mathrm{ml} 0.4 \mathrm{M}$ phosphate buffer ( $\mathrm{pH} 7.0$ ), $0.1 \mathrm{ml} 10 \mathrm{mM}$ sodium azide, $0.2 \mathrm{ml}$ reduced glutathione and $0.1 \mathrm{ml} 0.2 \mathrm{mM}$ hydrogen peroxide. The mixture was incubated at $37^{\circ} \mathrm{C}$ for $10 \mathrm{~min}$. Then the mixture was added with $0.4 \mathrm{ml} \mathrm{10 \%} \mathrm{TCA} \mathrm{to} \mathrm{stop} \mathrm{the} \mathrm{reaction,} \mathrm{allowed} \mathrm{for} 20 \mathrm{~min}$ centrifugation at $3200 \times \mathrm{g}$. The supernatant was assayed for glutathione content using Ellman's reagent. The activities were expressed as $\mu \mathrm{g}$ of GSH consumed/ $\mathrm{min} / \mathrm{mg}$ protein [43].

\subsection{5. lipid peroxidation ( $L P O)$}

LPO was estimated by the method of Okhawa et al[44]. One ml of liver homogenate was mixed with $0.2 \mathrm{ml} 4 \%(\mathrm{w} / \mathrm{v})$ sodium dodecyl sulfate, $1.5 \mathrm{ml} \mathrm{20 \%}$ glacial acetic acid in $0.27 \mathrm{M}$ hydrochloric acid ( $\mathrm{pH}$ 3.5) and $15 \mathrm{ml}$ of $0.8 \%$ thiobarbituric acid (TBA, pH 7.4). The mixture was heated in a hot water bath at $85^{\circ} \mathrm{C}$ for 1 $\mathrm{h}$. The intensity of the pink colour developed was read against a reagent blank at $532 \mathrm{~nm}$ following centrifugation at $1200 \mathrm{~g}$ for $10 \mathrm{~min}$. The concentration was expressed as $\mathrm{n}$ moles of MDA per mg of protein using 1,1,3,3,-tetra-ethoxypropane as the standard.

\subsection{Histopathological studies}

A small portion of liver was fixed in $10 \%$ neutral formalin, dehydrated in alcohol and then implanted in paraffin. Microtome sections of $4-5 \mu \mathrm{m}$ thickness were made by using a rotary microtome. The sections were stained with haematoxylin-eosin (H\&E) dye to observe histopathological changes $[45,46]$.

\subsection{Statistical analysis}

All the results were expressed as Mean \pm SEM. The statistical analysis was carried out by one-way ANOVA followed by Dunnett's multiple comparison tests (Graph pad Prism-5 software).

Author contributions: Conception- A.S.; Design- KR.Y.; A.S.; Supervision-A.S.; S.J.; Resources- KR.Y.; A.S.; S.J.; Materials- KR.Y.;S.J.; Data Collection and/or Processing- S.J.; K.G.; KR.Y.; Analysis and/or Interpretation-K.G.; KR.Y.; Literature Search- K.G.; KR.Y.; Writing-K.G.; KR.Y.; Critical Reviews-KR.Y.; A.S.; S.J.;K.G.

Conflict of interest statement: The authors declared noconflict of interest.

Ethics committee approval: Allexperimentsconducted in thisstudywereapprovedbyAnimalEthicsCommittee of KMCH College of Pharmacy in accordancewiththeguidelinesforthecareanduse of laboratoryanimals set by CPCSEA (KMCRET/PhD/01/2013-14) on 05-04-2014. 


\section{REFERENCES}

[1] Rui L. Energy metabolism in the liver. Compr Physiol. 2014; 4(1): 177-197. [CrossRef]

[2] Barker DJ. The developmental origins of chronic adult disease. Acta Paediatr Suppl. 2004; 93(446): 26-33.[CrossRef]

[3] Hood LL. Hood expounds the principles, practice and future of systems biology. Drug Discov Today. 2003; 8(10): 436-438.[CrossRef]

[4] Dikshit R, Gupta PC, Ramasundarahettige C, et al. Cancer mortality in India: a nationally representative survey. Lancet. 2012; 379(9828): 1807-1816.[CrossRef]

[5] Newman DJ, Cragg GM, Sander KM. Natural products as sources of new drugs over the period 1981-2002. J Nat Prod. 2003; 66: 1022-1037. [CrossRef]

[6] Quisumbing E. Medicinal Plants of the Philippines. Katha Publishing Co., Inc. Philippines, $1978 ; 773$.

[7] Ali SA, Sharief NH, Mohamed YS. Hepatoprotective Activity of Some Medicinal Plants in Sudan. Evid Based Complement Alternat Med. 2019; 2196315: 1-16. [CrossRef]

[8] Palaniappan R, Senguttuvan J, Kandasamy P, Subramaniam P. In vitro antioxidant properties of the traditional medicinal plant species, Ehretia microphylla Lam. and Erythroxylon monogynum Roxb. RJPBCS. 2014; 5(1): $247-$ 252.

[9] Mageswari S, Karpagam S. Evaluation of antimicrobial studies on root of Carmona retusa (vahl) masam. Int J Curr Pharm Res. 2015; 7(3): 60-63.

[10] Daniella MC, Kathlyn AL, Michael BP, Rodel JSV. Effect of Ehretia microphylla on the blood cholesterol and weight of ICR mice (Mus musculus). Natl J Physiol Pharm Pharmacol. 2018; 8(7): 983-987. [CrossRef]

[11] Yamamura S, Simpol LR, Ozawa K, et al. Antiallergic dimeric prenylbenzoquinones from Ehretia microphylla. Phytochemistry. 1995; 39(1): 105-110. [CrossRef]

[12] Tarke SR, Shanmugasundaram P. Antioxidant and Hepatoprotective activity of Ehretia laevis Roxb against paracetamol induced acute Hepatotoxicityin wistar rats. Research J. Pharm. and Tech. 2019; 12(12): 6143-6148. [CrossRef]

[13] Chandrappa CP, Govindappa M, Anil NV, Channabasava R et al. In Vitro Anticancer Activity Of Quercetin Isolated From Carmona retusa (Vahl.) Masam on Human Hepatoma Cell Line (HepG2). IOSR J Pharm Biol Sci. 2014; 9(6): 85-91.

[14] Mira A, Elsherbiny N, Alkhiary W, Shebl A, Tran H, Shimizu K. Hepatoprotective activities of the methanol extract of Angelica shikokiana and isoepoxypteryxin against Hepatocellular Carcinoma. Indian J Pharm Sci. 2017; 79(4): 576-584.[CrossRef]

[15] Aborehab NM, Waly NE. IL-6 and NFE2L2: A putative role for the hepatoprotective effect of N. Sativa, P. Ginseng and C. Sempervirens in AFB-1 induced hepatocellular carcinoma in rats. Toxicol Rep. 2019; 19(6): 457-464. [CrossRef]

[16] Alyoussef A, Al-Gayyar MMH. Cytotoxic and partial hepatoprotective activity of sodium ascorbate against hepatocellular carcinoma through inhibition of sulfatase-2 in vivo and in vitro. Biomed. Pharmacother. 2018; 103: 362-372. [CrossRef]

[17] Yuvaraja KR, Santhiagu A, Jasemine S, Gopalasatheeskumar K. Antioxidant potential of medicinally important plants Ehretia microphylla, Dipteracanthus patulus and Hydnocarpus laurifolia. IJBPAS. 2020; 9(2): 195-205.

[18] Huang ZQ, Chen P, Su WW, et al. Antioxidant Activity and Hepatoprotective Potential of Quercetin 7-Rhamnoside In Vitro and In Vivo. Molecules. 2018; 23(5): 1188.[CrossRef]

[19] Talwar S, Jagani HV, Nayak PG, Kumar N, Kishore A, Bansal P, et al. Toxicological evaluation of Terminalia paniculata bark extract and its protective effect against CCl4-induced liver injury in rodents. BMC Complement Alternat Med. 2013; 13(127): 1-11.

[20] Mahrous ABI, Farooq AW, Shaik R. Hepatoprotective effect of olive oil and camel milk on acetaminophen-induced liver toxicity in mice. Int J Med Sci Public Health. 2017; 6(1): 186-194.[CrossRef]

[21] Talwar S, Jagani HV, Nayak PG, et al. Toxicological evaluation of Terminalia paniculata bark extract and its protective effect against CCl4-induced liver injury in rodents. BMC Complement Altern Med. 2013; 13 : 127. [CrossRef]

[22] Arivazhagan P, Thilakavathy T, Panneerselvam C. Antioxidant lipoate and tissue antioxidants in aged rats. J Nutr Biochem. 2000; 11(3): 122-127.[CrossRef] 
[23] Eesha BR, Mohanbabu Amberkar V, Meena Kumari K, et al. Hepatoprotective activity of Terminalia paniculata against paracetamol induced hepatocellular damage in Wistar albino rats. Asian Pac J Trop Med. 2011;4(6):466-469. [CrossRef]

[24] Pietta PG. Flavonoids as antioxidants. J Nat Prod. 2000; 63(7): 1035-1042. [CrossRef]

[25] Gopalasatheeskumar K. Significant Role of Soxhlet Extraction Process In Phytochemical Research. MJPMS. 2018; $7(1): 43-47$.

[26] Sivakumar G, Gopalasatheeskumar K, Gowtham K, Sindhu E, Akash Raj K, Rajaguru B, Sriram K, Kalaichelvan V K. Phytochemical analysis, Antioxidant and Antiarthritic activities of different solvent extract of Aegle marmelos L. unripe fruit. Research J Pharm and Tech. 2020; 13(6): 2759-2763. [CrossRef]

[27] Gopalasatheeskumar K, Parthiban S, Manimaran T, Boopathi T. Phytochemical Screening on Various Extracts (Benzene, Ethanolic and Aqueous) of Stem Parts of Zanthoxylum rhetsa (Roxb.) Dc. IJUPBS. 2017; 6(2): 79-91.

[28] Rajeshkumar S, Tamilarasan B, Sivakumar V. Phytochemical Screening and Hepatoprotective Efficacy of Leaves Extracts of Annona squamosa against Paracetamol Induced Liver Toxicity in Rats. Int J Pharmacognosy. 2015; 24: 178-85. [CrossRef]

[29] Yuvaraja KR, Santhiagu A, Jasemine S, Gopalasatheeskumar K. Hepatoprotective activity of Chloroform and Ethyl acetate extract of Dipteracanthus patulus against Paracetamol induced Hepatotoxicity in rats through Antioxidant mechanism. Research J Pharm and Tech. 2020; 13(1): 203-208.[CrossRef]

[30] Ashok Kumar BS, Lakshman K, Arun Kumar PA, et al. Hepatoprotective activity of methanol extract of Amaranthus caudatus Linn. against paracetamol-induced hepatic injury in rats. Zhong Xi Yi Jie He Xue Bao. 2011; 9(2): 194-200.

[31] Meharie BG, Amare GG, Belayneh YM. Evaluation of Hepatoprotective Activity of the Crude Extract and Solvent Fractions of Clutia abyssinica (Euphorbiaceae) Leaf Against CCl4-Induced Hepatotoxicity in Mice. J Exp Pharmacol. 2020; 12: 137-150. [CrossRef]

[32] Girish C, Pradhan SC. Hepatoprotective activities of picroliv, curcumin, and ellagic acid compared to silymarin on carbon-tetrachloride-induced liver toxicity in mice. J Pharmacol Pharmacother. 2012; 3(2): 149-155.

[33] Soliman MM, Abdo Nassan M, Ismail TA. Immunohistochemical and molecular study on the protective effect of curcumin against hepatic toxicity induced by paracetamol in Wistar rats. BMC Complement Altern Med. 2014; 14: 457. [CrossRef]

[34] Kazemifar AM, Hajaghamohammadi AA, Samimi R, Alavi Z, Abbasi E, Asl MN. Hepatoprotective Property of Oral Silymarin is Comparable to N-Acetyl Cysteine in Acetaminophen Poisoning. Gastroenterology Res. 2012; 5(5): 190194. [CrossRef]

[35] Zainul Amiruddin Z, Farah Hidayah K, Teh Lay K, Zaki Salleh M. Hepatoprotective and antioxidant activities of Dicranopteris linearis leaf extract against paracetamol-induced liver intoxication in rats. Pharm Biol. 2020; 58(1): 478-489. [CrossRef]

[36] Reitmann S, Frankel S. A colorimetric method for the determination of serum glutamic oxalacetic and glutamic pyruvic transaminases. Am J Clin Pathol. 1957; 28(1): 56-63. [CrossRef]

[37] Fawcett JK, Scott JE. A rapid and precise method for the determination of urea. J Clin Pathol. 1960; 13(2): 156-159. [CrossRef]

[38] Kammeraat C. Modification of the alkaline picrate assay for creatinine to prevent spuriously elevated values by keto acids. Clin Chim Acta. 1978; 84(1-2): 119-128. [CrossRef]

[39] Kesari AN, Gupta RK, Singh SK, Diwakar S, Watal G. Hypoglycemic and antihyperglycemic activity of Aegle marmelos seed extract in normal and diabetic rats. J Ethnopharmacol. 2006; 107(3): 374-379. [CrossRef]

[40] Sinha AK. Colorimetric assay of catalase. Anal Biochem. 1972; 47(2): 389-394. [CrossRef]

[41] Ellman GL. Tissue sulfhydryl groups. Arch Biochem Biophys. 1959;82(1):70-77. [CrossRef]

[42] Sunil C, Duraipandiyan V, Ignacimuthu S, Al-Dhabi NA. Antioxidant, free radical scavenging and liver protective effects of friedelin isolated from Azima tetracantha Lam. leaves. Food Chem. 2013;139(1-4):860-865. [CrossRef]

[43] Mascarenhas RW, Shailajan S, Menon S. Antioxidant and hepatoprotective activity of Flemingia tuberosa Dalzell in CCl4-induced hepatotoxicity in rats. J Appl Pharm Sci. 2020; 10(6): 32-38.

[44] Ohkawa H, Ohishi N, Yagi K. Assay for lipid peroxides in animal tissues by thiobarbituric acid reaction. Anal Biochem. 1979; 95(2): 351-358. [CrossRef] 
[45] Danish A, Vikas K, Amita V, Girija SS, Manju S. Antidiabetic, antioxidant, antihyperlipidemic effect of extract of Euryale feroxsalisb with enhanced histopathology of pancreas, liver and kidney in streptozotocin induced diabetic rats. Springerplus. 2015; 4(315): 1-17.[CrossRef]

[46] Anyasor GN, Idowu DP, Nabofa W. Evaluation of the hepatoprotective effect of oral administration of aqueous fraction of methanolic extract of Costus afer leaves during induction of hepatocellular carcinoma with diethylnitrosamine in rats. Comp Clin Pathol. 2020; 29: 733-744. [CrossRef]

This is an open access article which is publicly available on our journal's website under Institutional Repository at http://dspace.marmara.edu.tr. 